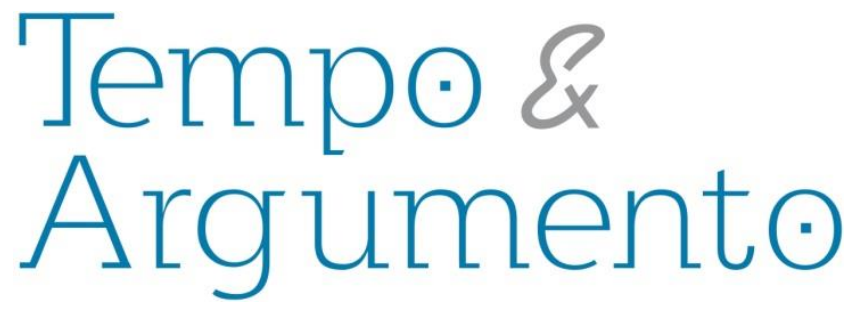

\title{
Nos acordes da raça: a era do jazz no meio afro-brasileiro*
}

\begin{abstract}
Resumo
As jazz-bands emplacaram no Brasil na década de 1920. Fizeram um sucesso extraordinário e impulsionaram as chamadas danças e músicas modernas norte-americanas. Que jazz essas bandas tocavam? Pode-se dizer que essa expressão musical, na medida em que foi apropriada pela população afro-brasileira, permaneceu igual àquela entoada pelos norteamericanos, ou adquiriu uma "cor local"? O artigo tem a intenção de mapear a presença do jazz no meio negro de São Paulo na década de 1920 e demonstrar como o estilo de origem afrodiaspórica impactou a vida cultural desse segmento populacional, influenciando inclusive suas experiências de sociabilidade.
\end{abstract}

Palavras-chave: Jazz - História. Negros. Diáspora Africana.

\section{Petrônio Domingues}

Doutor em História Social pela Universidade de São Paulo (USP). Estágio Pó-Doutoral na

Universidade de New Jersey - Estados Unidos e Estágio Pos-Doutoral na Universidade Federal do Rio de Janeiro (UFRJ). Professor na Universidade Federal de Sergipe (UFS). Bolsista Produtividade CNPq.

São Cristóvão - SE - Brasil pjdomingues@yahoo.com.br

\section{Para citar este artigo:}

DOMINGUES, Petrônio. Nos acordes da raça: a era do jazz no meio afro-brasileiro. Tempo e Argumento, Florianópolis, v. 10, n. 25, p. 66 - 98, jul./set. 2018.

\section{DOI: $10.5965 / 2175180310252018066$}

http://dx.doi.org/10.5965/2175180310252018066

\footnotetext{
* O autor faz um agradecimento especial a Ruan Levy Andrade Reis, cujas contribuições foram de suma importância para a compilação das fontes e as reflexões de aspectos do artigo.
} 


\title{
In the race chords: the jazz era in the Afro-Brazilian environment
}

\begin{abstract}
Jazz-bands came to Brazil in the 1920s. They made striking success and boosted the so-called modern dances and American songs. What kind of jazz did these bands play? Could we assume that this musical expression, as it was appropriated by the Afro-Brazilian population, remained the same as that sung by the Americans? Or did it develop a "local shade"? The aim of the article is to map the Jazz presence in the black population of São Paulo in the 1920s and to illustrate how the Afro-diasporic style influenced the cultural life of this population, even their sociability experiences.
\end{abstract}

Keywords: Jazz. Music. Black. Race. Afro-Diaspora.

São Paulo nos anos 1920. Em um sábado à tarde qualquer da pulsante e cosmopolita cidade, vemos negras e negros enfronhados ansiosos com os preparativos no barbeiro, na cabelereira, em brechós, lojas de cosméticos, bijuterias e assessórios para desfrutarem de um programa de entretenimento. Esperaram muito por este dia, depois de terem recebido o convite ou lido nos jornais O Clarim da Alvorada, Elite ou A Voz da Raça as chamadas tentadoras para o baile. Alguns tinham a expectativa de ostentar pelo salão os estilos estéticos e comportamentais da moda; outros ardiam pela oportunidade de rever - e dançar com - aquela linda moça ou aquele elegante rapaz com quem tantos olhares trocaram na última tertúlia. Havia aqueles que almejavam ali encontrar ou fortalecer os laços de sua identidade racial. Muitos queriam mesmo era se 
divertir "ao som das risadas metálicas do sumptuoso Jazz Band" e se esquecer por um instante da difícil "vida com cambio baixo e feijão a $2 \$ 500$ o quilo". ${ }^{2}$ Eram os admiradores da Jazz Band Ba-ta-clan33, da Jazz Floresta ${ }^{4}$ ou da Orquestra Elite. ${ }^{5}$ Assim como poderiam ser fãs do maestro Benedito Vianna ${ }^{6}$, Benedicto dos Santos ${ }^{7}$ ou Badalaro. ${ }^{8}$ Para a maioria, era a oportunidade de estar com os seus pares, experimentando a vida pública num dos poucos espaços onde o "preconceito de cor" não se apresentava como um limite, usufruindo da boa música e incontornável dança, confraternizando-se com os velhos “patrícios” ou fazendo novas amizades. No caso das moças, a intenção era exibir suas belas "toilettes" ou saia-balão, redondas, engomadas. Cada uma queria ser mais vistosa do que as outras. Muitas eram cozinheiras de forno e fogão em casas de famílias abastadas. Quanto aos homens, também procuravam se trajar bem, com suas calças listradas, um paletó preto ou azul-marinho, um colete branco, uma camisa de peito engomada ou então um tipo de camisa de renda. "Alguns tinham uma boa situação social. Mas era questão de ser chofer, cozinheiro ou funcionário público (situação que dificilmente passava de contínuo)” (LEITE, 1992, pp. 44-45).

Depois de devidamente trajados, elas e eles saíam de suas casas na região do Lavapés, na Baixada do Glicério, do Bexiga, da Barra Funda e se dirigiam ao centro da cidade. Sede dos clubes dançantes 13 de Maio, Kosmos, Auriverde, 15 de Novembro, Smart, Elite Flor da Liberdade, 28 de Setembro, União da Mocidade, Paulistano, Pendão Brasileiro, Chuveiro de Prata, Cruzeiro do Norte, Ituano, situados nos movimentados endereços das ruas Quintino Bocaiúva, Florêncio de Abreu, Quinze de Novembro e Conceição. ${ }^{9}$ Ou salões Victória, Giusepe Verdi e Itália Fausta. ${ }^{10}$ Nesses locais o baile começava.

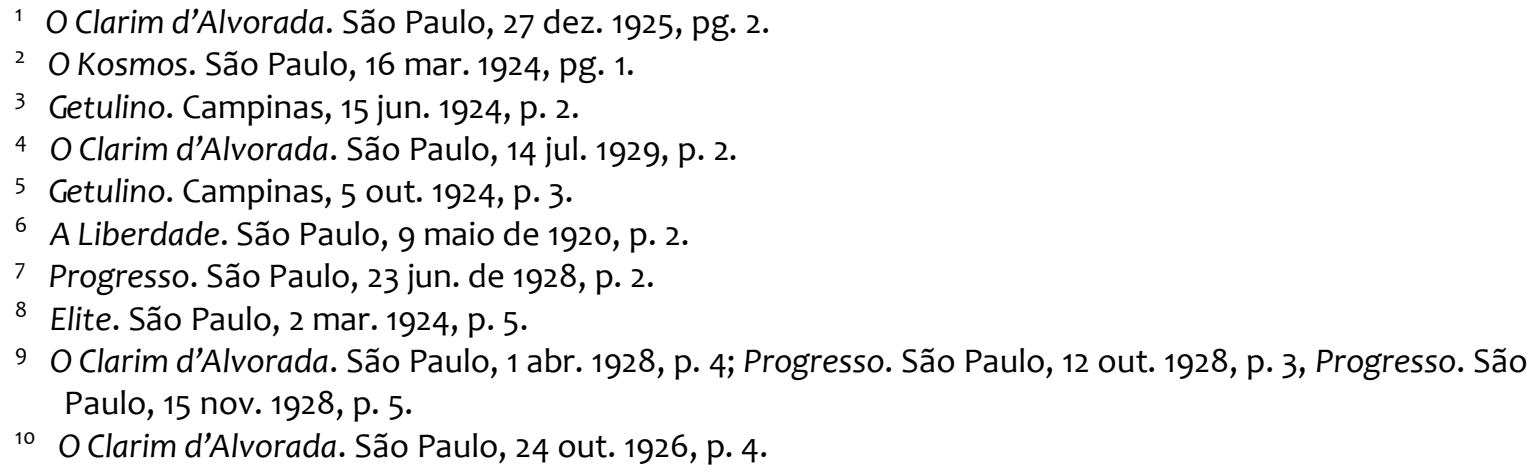


Às vezes, um discurso abria a noite, sendo acompanhado de encenações dramáticas e declamações de poesias. Era comum funcionar nas dependências do salão uma chapelaria e um bar, quando poderia ser oferecida comida e bebida: doces, salgados, sucos, gasosas, vinhos, licores e chopps. Como momento culminante, o baile per si. A orquestra subia ao palco e começavam as músicas e "contradanças". Homens convidavam, mulheres aceitavam ou não. "Quando não quero dançar/ Eu digo que me dói o pé"11, dizia em poema Deocleciano Nascimento a respeito da postura das mulheres. No entanto, havia bailes com revezamento: uma hora os cavalheiros tiravam as damas, outra, as damas tiravam os cavalheiros.

No meio da noite, a "partida" poderia ser interrompida para um concurso de dança, se não de "melhor traje". Ou algo mais que preenchesse o intervalo dos músicos, que retornavam como um turbilhão para a parte final da festividade. Já passou das 20 ou 21 horas (para as “matinées") ou já estava perto do sol nascer (para as “soirées”), quando a banda parava e o baile acabava. Agora, era voltar para casa, já não tão elegante, nem com a mesma energia, depois de tanta festividade, e guardar na memória os momentos marcantes de mais um baile animado e descontraído. O evento ainda renderia muito assunto durante a semana, enquanto começavam os preparativos para o próximo. Afinal, "dentre todos os divertimentos, o que mais nos proporciona prazeres verdadeiros é, sem dúvida o baile", sobretudo quando musicado por uma jazz-band. ${ }^{12}$

Nascido do encontro de duas tradições culturais (a africana ocidental e a europeia) em Nova Orleans, nos Estados Unidos, o jazz recebeu a influência do blues, dos spirituals (canções de trabalho) e do ragtime, especialmente (STEARNS, 1956). Não há consenso quando isso ocorreu exatamente. A primeira década do século XX teria sido a de sua formação e/ou consolidação; e o período de 1900 a 1920 como o de sua consagração como gênero específico nos Estados Unidos, quando deixou de ser visto apenas como uma música para se tornar o estado de espírito de uma era, a "era do jazz", como tão bem definiu Scott Fitzgerald a atmosfera cultural dos "anos vinte": de euforia desenvolvimentista, entusiasmo coletivo, renovação de hábitos e costumes, ascensão de

\footnotetext{
11 Getulino. Campinas, 19 out. 1924, p.2.
}

12 Elite. São Paulo, 17 fev. 1924, p. 1. 
novos estilos e inventos tecnológicos relacionados ao consumo, fruição e bem-estar (FITZGERALD, 1965).

O jazz foi a primeira manifestação musical dos negros nos Estados Unidos a romper a barreira de cor e alcançar um sucesso assombroso em todas as classes sociais, convertendo-se em um símbolo cultural da nação. Foi assim que ele passou a ser divulgado em todos os cantos e recantos do país, circulando para além da fronteira continental e causando furor como nova mania musical (BILLARD, 2001). Em Paris, os artistas vanguardistas ficaram fascinados com uma sonoridade que rompia as barreiras do formalismo clássico, do puro e simples aperfeiçoamento técnico, para valorizar a liberdade de formas (improviso), o swing (síncope) e a infusão do emocional (que toca o coração) à arte. O jazz - com toda sua mística de primitivismo, espontaneidade, exotismo e sensualidade - foi adotado como a expressão musical mais genuína da modernidade (BLAKE, 1999). Entrou em cena no plano transnacional. Viajou nos fluxos de bens simbólicos e redes de conexões culturais pela Europa e pelas Américas, chegando ao Brasil (BORGE, 2018).

Podemos perceber que aqui, antes de se falar em jazz, as chamadas danças e músicas modernas norte-americanas - ragtime, one-step, two-step, fox-trot e mais anteriormente o cake-walk - já eram conhecidas (VASCONCELLOS, 1977; TINHORÃO, 1998; ABREU, 2017). Portanto, a presença das matrizes fundantes do jazz no Brasil é antiga. Remonta ao início do século XX, porém foi a partir da década de 1920 que aqueles gêneros, agrupados sob a genérica denominação de jazz, emplacaram de maneira extraordinária. "A coisa pegou de tal maneira”, afirma Sérgio Cabral, "que a resposta a um convite para um baile ou chá dançante passou a ser sempre a mesma: É com jazz?" (CABRAL, 2007, p. 114).

Em pesquisa sobre a história cultural da paulicéia desvairada nesse período, Nicolau Sevcenko salienta como, entre os segmentos sociais mais elitizados da população, proliferaram os bailes e ambientes de dança relacionados à "indústria do lazer", assim como expandiram os clubes, as sociedades dançantes e as casas dedicadas aos music-hall. Várias lojas da "fina flor" da cidade, para atrair a clientela feminina, tiveram que transformar o seu tradicional "chá das cinco" em um, a partir de então, 
apinhado “chá dançante”. As músicas que tocavam nesses lugares eram aquelas voltadas às "chamadas danças modernas ou americanas" - fox-trot, one e two-steps, ragtime e o jazz -, um tipo de sonoridade "variado na classificação, mas uniforme no acento rítmico" (SEVCENKO, 1992, p. 90).

Por outro viés, o memorialista Jacob Penteado assinala que, em 1921, nos bairros de imigrantes do Brás e do Belenzinho, eram numerosas as "sociedades-recreativas" cujos salões de bailes capitularam as novas tendências rítmicas e sonoras. Nas palavras de Penteado, as “danças de outrora - “xotes, polcas, mazurcas, quadrilha, lanceiros, 'pas-dequatre"” - cederam lugar a outras, "mais modernas, tais como tango, rancheira, fox-trot, one-step, two-step, ragtime (influência americana, que já começava a invadir-nos), charleston, habanera e o velho e muito caboclo maxixe" (PENTEADO, 1963, pp. 47-48). Outro memorialista, Sylvio Floreal, relata em obra de 1925 como os gêneros e danças modernas tomaram conta dos clubes, bailes e salões de dança populares. Quando o sol esmaecia no "poente numa agonia langorosa e prolongada", a Rua Direita, no centro de São Paulo, regurgitava da patuleia: “Entro na Confeitaria Fasoli. O vasto salão, sempre cheio de homens e mulheres, delira entusiasticamente, animado pela música que toca sempre uns pot-pourri nervosos e fox-trots saltitantes à jazz-band" (FLOREAL, 2003, p. 105).

A nova coqueluche também reverberou no meio negro de São Paulo. Reunidos em torno de sociedades de diferentes tipos - recreativas, dramáticas, literárias, beneficentes, desportivas e dançantes -, os autodeclarados “homens de cor” investiam numa intensa atividade social que, inclusive, ultrapassava os limites da capital paulista, já que muitas de suas ações coletivas ocorriam em cidades vizinhas. Tais atividades eram as mais variadas possíveis: comemorações cívicas, homenagens a personalidades, excursões, concursos os mais diversos, como de beleza, de blocos carnavalescos; quermesses, competições desportivas, convescotes etc. ${ }^{13}$ Devido ao grande número de sociedades dançantes e recreativas, pode-se presumir que a maioria tinha por objetivo proporcionar opções de lazer, por meio de festas e bailes específicos, que não estavam ligados às "sociedades-

\footnotetext{
3 Sobre a vida associativa dos negros em São Paulo nesse período, ver BUTLER, 1998; ANDREWS, 1998;
} PIRES, 2006; PINTO, 2013. 

um público amplo, fiel e sedento por novidades. Não tardou e o "som contagiante das jazz-bands" se tornou um eficaz chamariz dos bailes dos afro-paulistas. Não só dos bailes, como também das festas comemorativas, reuniões familiares, folganças carnavalescas ${ }^{14}$ e até dos concursos de beleza ${ }^{15}$, ocasiões em que não se desperdiçava a oportunidade de apreciar as "musicas modernas".

Contudo, não basta argumentar que a cultura jazzística chegou ao Brasil e ecoou nas experiências de sociabilidade da população negra de São Paulo nos anos 1920. Que jazz era esse? Pode-se dizer que essa expressão musical, na medida em que foi apropriada por esse grupo, permaneceu igual àquela entoada pelos norte-americanos, ou adquiriu uma "cor local"? Onde, como e em quais eventos da comunidade negra poder-se-ia ouvir e dançar o gênero? Quem eram as pessoas que participavam desses eventos? O que era uma jazz-band? Quais bandas e maestros ganharam destaque no período? Afinal, o que se entendia por jazz? São esses questionamentos desafiadores que buscaremos responder, a partir da consulta fundamentalmente à imprensa negra - termo que se convencionou designar para o conjunto de jornais feitos por afro-brasileiros e dedicados à sua vida, questões e mundo no qual estavam inseridos. ${ }^{16}$ Além de traçar uma espécie de etnografia histórica do jazz no meio negro, o artigo pretende demonstrar como as jazz-bands foram importantes para a vida cultural desse segmento populacional.

\section{As jazz-bands}

Se os ritmos norte-americanos ditos modernos já pairavam por São Paulo no início do século XX, foi na década de 1920 que se sentiu fortemente a influência da "era do jazz", nas mais distintas áreas: no teatro de revista, no cinema, nas incipientes emissoras de rádio, nos jornais, nas revistas, na edição de partituras, na emergente indústria

14 O Clarim d'Alvorada. São Paulo, 20 fev. 1927, p. 4.

15 Concurso de Belleza. Getulino. Campinas, 21 out. 1923, p. 1.

16 Sobre a Imprensa Negra, ver BASTIDE, 1951, p. 50-78; FERRARA, 1986; DOMINGUES, 2008, p. 19-58; ALBERTO, 2011; REIS, 2017. 
fonográfica, nas peças publicitárias, no comércio de cosméticos, moda e produtos de beleza, sem falar do show business. O vocábulo jazz passou, paulatinamente, a fazer parte do cotidiano paulista nesse momento. Algumas orquestras incorporaram o gênero em seu repertório, outras foram batizadas e rebatizadas tomando de empréstimo o vocábulo.

Surgiram a Jazz-band República - que era ligada ao cinema homônimo e alcançou grande fama na cidade -, o Marion Jazz-band, do Theatro Sant'Anna, em 1921; Jazz-band Palácio, em 1922, do Palácio Theatro; Jazz-band Paulista, do Real Cabaret, em 1923; Jazz Band Manon, em 1924 (MORAES, 1995, p. 164), entre muitos outros grupos. No Rio de Janeiro, o maestro Romeu Silva "modernizou” a sua Orquestra Sul-Americana-Brasileira. Adaptando instrumentos e arranjos típicos de "música de pancadaria”, ele a transformou na Jazz-Band Sul-Americana em 1921. ${ }^{17}$ O grupo "Os Oito Batutas", do qual fazia parte Pixinguinha e outros membros importantes do círculo de música popular do Rio de Janeiro, também se revestiu de tons "modernos" quando de sua volta da turnê por Paris em $1922 .{ }^{18}$ O próprio Pixinguinha passou a tocar saxofone, instrumento típico de jazz, e o repertório do conjunto passou a contar com títulos, ritmos e melodias sob a tônica das músicas norte-americanas ${ }^{19}$, chegando a mudar o próprio nome para "Bi-Orquestra Os Batutas" e assumindo o "gênero jazz-band" (SEIGEL, 2009, p. 106).

Fato é que as jazz-bands, com diferentes sentidos, públicos e objetivos, multiplicaram-se, desencadeando uma explosão feérica no cenário artístico-musical (SEVERIANO; MELLO, 1997, p. 50; LABRES FILHO, 2014, p. 75). Quando Antonio Ferro - um jornalista, escritor e político português que firmou estreitos contatos com os modernistas brasileiros - realizou uma conferência no Teatro Lírico, no Rio, em julho de 1922, e a replicou em São Paulo no Teatro Municipal, em setembro, e em mais dois lugares, ele enfatizou: “O Jazz-Band a encarnado e negro, a todas as cores, é o relógio que melhor dá

17 Romeu Silva e sua então “Orquestra Sul-Americana-Brasileira” animavam a primeira viagem marítima da Munson Steamship Line entre Rio de Janeiro e Nova Yorque. Ao retornar, Silva incorporou o jazz à sua orquestra, que passou a se chamar "Jazz-Band Sul-Americana" (SEIGEL, 2009, p. 102).

18 Sobre a trajetória do grupo Os Oitos Batutas, nesse período, e seus intercâmbios na rede do transnacionalismo negro, ver MARTINS, 2014; SHAW, 2018.

19 "In Paris, [Arnaldo] Guinle gave Pixinguinha a saxophone, which he took up upon his return to Rio with skill and gusto and played for the rest of his carrer. [...] Their repertoire shifted as well, incorporating an array of jazzy titles, rhythms, and melodies" (SEIGEL, 2009, p. 106). 
as horas de hoje, as horas que passam a dançar, horas fox-trotadas, nervosas... No JazzBand, como num écram, cabem todas as imagens da vida moderna". Em outro momento da palestra, Ferro frisava que a influência da "arte negra sobre a arte moderna" era indiscutível: “O momento é um negro. O jazz-band é o xadrez da hora [...], o ex-libris do século" (FERRO, 1922, pp. 55-56, 66-67).

Em 3 de fevereiro de 1929, o jornal da imprensa negra O Clarim d'Alvorada republicou uma entrevista dada pelo pandeirista Alfredo Alcântara, um dos integrantes dos "Batutas", grupo musical que "tanto sucesso tem alcançado não só no Brasil, como em Portugal e França". O intuito de Alcântara era denunciar o racismo que ele observou ser ainda forte no Rio Grande do Sul, estado onde esteve em turnê, mas a matéria nos serve de janela para discutir dois aspectos sobre as jazz-bands nacionais: a sua formação e o seu repertório. O jornalista abre a matéria elogiando a orquestra e, em seguida, lista a sua composição - o nome dos músicos e os instrumentos que tocam: "Pixinguinha (flauta); Donga (banjo); Vantuil (trombone); Martins (piano); Paulo (pistom); Francisco (tuba); Benedicto (bateria); Alfredo (pandeiro); Paschoal (saxofone) e Benicio (tenor)". ${ }^{20}$ De modo geral, é difícil definir quais os instrumentos que faziam parte de uma jazz-band, uma vez que contavam sempre com muita variação entre elas, mas é possível traçar alguns elementos básicos. Em estudo sobre a música popular brasileira e suas conexões transnacionais, Rafael Velloso assinala como o maestro Romeu Silva se inspirou ao ver, nos Estados Unidos, uma jazz-band "formada por: dois trombones, dois trompetes, contrabaixo, piano e bateria" (VELLOSO, 2005, p. 814). Essa inspiração o levou a criar a Jazz-Band Sul-Americana.

Ao se cruzar essas duas bases de informações, percebemos que as bandas de jazz eram formadas majoritariamente por instrumentos de sopro, responsáveis pela melodia do conjunto. Nos “Batutas", seis eram de sopro (contra dois de percussão, um de teclas e um de cordas - ou seja, $60 \%$ do total) e, na banda que Romeu Silva viu nos Estados Unidos, o sopro também era o forte do grupo (quatro sopros contra três outros, sendo um tipo de cada). Para reforçar a importância dos instrumentos de sopro para o jazz, basta lembrar-se de dois nomes legendários do estilo: Louis Armstrong e seu potente

\footnotetext{
20 “Curiosa Entrevista Dada à Crítica”. O Clarim d'Alvorada. São Paulo, 3 fev. 1929, p. 2.
} 
saxofone, e Miles Davis, com seu criativo e virtuoso trompete. Outras características das bandas de jazz eram a presença de ao menos um instrumento de corda, que poderia ser o banjo, contrabaixo, cavaquinho ${ }^{21}$, violino ${ }^{22}$ e/ou violão. O piano era peça indispensável. Fazendo-se presente desde a primeira banda de jazz nos Estados Unidos (Original Dixieland Jazz Band), ficava encarregado tanto pela base rítmica e harmônica, auxiliado pelas cordas, como podia executar trechos melódicos, a exemplo das mais famosas peças de ragtime de Scott Joplin. Todavia, nenhum instrumento era tão significativo para as jazz-bands quanto a bateria. Originada por ocasião das primeiras expressões do jazz em Nova Orleans, recebeu a influência das bandas militares, que eram compostas de bumbo, surdo, caixa e pratos, tocados separadamente. Tocar tais instrumentos ao mesmo tempo, por meio de um único músico, foi invenção do jazz. Não à toa, a bateria estava sempre presente nas bandas. Quando Alberto Ikeda entrevistou em São Paulo um legendário baixista, de alcunha "Mimi", ouviu deste que a bateria "tipo norte-americana" foi, a princípio, o que mais caracterizou o jazz no Brasil. Evidentemente, o ritmo também tinha importância, porém a bateria se distinguia como sinônimo do novo gênero (IKEDA, 1984, p. 118).

Outro aspecto das jazz-bands que precisa ser abordado diz respeito ao repertório. A banda dos "Batutas", ao mesmo tempo em que possuía instrumentos ligados à tradição musical euro-americana, como o banjo, o sax e a própria bateria, não abria mão do pandeiro. Ora, isso é sinal de que as jazz-bands brasileiras não eram iguais às estrangeiras, nem tocavam as mesmas músicas. Para quê um pandeiro numa banda de jazz? Esta até poderia incorporar sonoridades incomuns, a exemplo de "buzina de automóvel, campainha, lata de querosene e chacoalho", como apontou Horácio Cunha em reportagem d'O Clarim d'Alvorada, ${ }^{23}$ mas não nos parece o caso do pandeiro. Se Alfredo Alcântara conseguia tocar jazz com esse instrumento, isso configurava uma inovação. O jazz nacional se diferenciava daquele produzido nos Estados Unidos não só

\footnotetext{
21 Micol Seigel aponta que, quando da volta dos "Batutas" de Paris, estes incorporaram o "cavaquinhobanjo", um instrumento que realmente se aparenta com o banjo, mas guarda suas diferenças físicas (composto por quatro cordas, ao invés das cinco presentes no banjo), de timbre e sonorida de (SEIGEL, 2009, p. 106).

22 Getulino. Campinas, 15 jun. 1924, p. 2.

23 CUNHA, Horácio. “Os pretos e a música”. O Clarim d’Alvorada. São Paulo, 17 abr. 1927, p. 2-3.
} 
no tocante à composição instrumental, mas também musical. O pandeirista estava ali para tocar outras músicas - as ditas "nacionais" (maxixes, sambas, marchas, choros, cateretês, rancheiras, emboladas sertanejas) -, as quais também eram executadas pelas jazz-bands.

Assim, as orquestras brasileiras dedicadas ao jazz, mesmo aquelas que adotavam o estilo no próprio nome, não tocavam exclusivamente as músicas modernas norteamericanas. Pelo contrário, elas amiúde investiam em diversas sonoridades, dependendo do contexto (local da apresentação, natureza do evento, perfil do público, exigências da indústria fonográfica etc.). Desde o início da moda do jazz, as orquestras pelo Brasil afora realizaram reformulações, arranjos e adaptações em seu repertório, mesclando os ritmos estrangeiros em voga e os gêneros do cancioneiro popular brasileiro consagrado. Foi com essa nova "roupagem" musical que elas se reinventaram (e sobreviveram) sob o selo jazzband. Eis uma peculiaridade marcante do jazz à brasileira: o hibridismo, instrumental e sonoro.

Evidências disso são fartas. A primeira está na própria entrevista de Alfredo Alcântara republicada n'O Clarim d'Alvorada. Depois de ouvir as reclamações sobre a existência do racismo no Rio Grande do Sul e o relato da boa receptividade que os "Batutas" tiveram na cidade de Porto Alegre, o jornalista lhe perguntou a respeito do show que realizaram: "Quais foram as músicas que mais agradaram [o público]?”, daí o pandeirista respondeu: “o maxixe ‘Lavadeira' e a marcha ‘Fuzarca”. ${ }^{24}$ Fica notório que os "Batutas", mesmo sendo uma jazz-band estruturada com instrumentos típicos (como a bateria, o banjo, o piano e os sopros), tocava estilos diversificados, entoando um repertório misto.

Outra evidência é a peça de publicidade de uma jazz-band da cidade de Campinas, que, em duas edições consecutivas do jornal Getulino, anunciava: "Quereis dançar no mais puro estilo 'paulista' e deliciar-vos com os mais belos 'chorinhos' da capital? Contratai para os vossos bailes o Jazz-Band Ba-Ta-Clan - O primeiro de rapazes de cor, em Campinas. Sob direção do 'violino-chorista' Julio Mariano". 25 Podemos mencionar ainda

\footnotetext{
24 “Curiosa Entrevista Dada à Crítica”. O Clarim d'Alvorada. São Paulo, 3 fev. 1929, p. 2.

25 Getulino. Campinas, 15 jun.1924, p. 2; 13 jul. 1924, p. 1.
} 
uma nota, divulgada no jornal Progresso, da cidade de São Paulo: “O jazz Rio Serenaders, formado por artistas desta Capital, é aplaudidíssimo, todas as vezes que se faz ouvir em maxixes (cantados especialmente) e outras músicas verdamarelamente brasileiras". ${ }^{26}$ Percebemos que as jazz-bands Ba-Ta-Clan e Rio Serenaders executavam chorinhos, maxixes, mesmo "cantados especialmente", e "outras músicas verdamarelamente brasileiras".

O que nos parece mais plausível para as jazz-bands nacionais, ou pelo menos as afropaulistas, é o que o jornal O Kosmos noticiou sobre um baile de domingo de carnaval em março de 1924: "o nosso Kosmos", um dos mais importantes clubes negros na época, "resplandecente de luxo, e ornamentado por lindas figurinhas, convidava seus habitués a dançar seguindo os passos jazz-bandicos de sua deliciosa orquestra." 27 Quando da chegada do jazz em São Paulo, as antigas “orquestras de salão” já atuavam a pleno vapor, animando bailes, festas, reuniões sociais e outros eventos. Essas orquestras, inclusive, mantinham em seu repertório gêneros musicais norte-americanos, como o cake-walk, one e two-steps, foxtrot e ragtime. A partir da década de 1920, essas influências se fundiram ao jazz e passaram a representar um conjunto de "músicas modernas", momento em que as antigas orquestras se metamorfosearam, adotando novos instrumentos, novas sonoridades e até um novo swing (“os passos jazz-bandicos”), sem renegar aquilo que já se propunham a fazer. ${ }^{28}$

Em maio de 1933, A Voz da Raça veiculou a nota de que o "Bloco 13 de maio" realizou uma "encantadora festa atraindo uma seleta concorrência", sendo que o "Jazz do nosso amigo Conegunes muito realçou nesta festa executando as músicas mais variadas do seu vasto repertório". 29 Um ano depois, o periódico reportou que a Jazz Band Espírito Santo “abrilhantou” o espetáculo dramático da "Delegação da Frente Negra Brasileira" de Tietê, cidade do interior paulista, tocando "valsa", "marchinha",

\footnotetext{
6 Progresso. São Paulo, 28 abr. 1929, p. 1.

7 O Kosmos. São Paulo, 16 mar. 1924, p. 1.

${ }^{28}$ Conforme ressalta Leandro Barsalini (2018, p. 66), “não se deve considerar as jazz bands brasileiras necessariamente como bandas cujo repertório era estritamente executado na linguagem jazzística; e sim como sinônimo de grupo que produzia um som dançante e moderno, conectado às novidades sonoras e visuais vindas do exterior, refletidas em seus trajes, sua postura e em sua instrumentação".

29 A Voz da Raça. São Paulo, 13 maio 1933, p. 2.
} 
“serenata",30 "fox [trot]", "rancheira" e, por fim, o "hino da Gente Negra”. ${ }^{31}$ Essas fontes indicam, uma vez mais, que as autodenominadas jazz-bands agitavam as noites paulistas com um repertório musical eclético, mesclando na mesma exibição "valsa", "marchinha" "rancheira" - gêneros tradicionais, já largamente conhecidos no Brasil - e o moderno "fox" norte-americano.

As festividades negras também eram embaladas por orquestras, convertidas em jazz-bands. Foi dessa forma, aliás, que a palavra jazz apareceu pela primeira vez na imprensa negra. O Getulino, de Campinas, noticiou que, no dia 30 de setembro de 1923, aconteceria o encerramento do concurso de beleza promovido pelo jornal. Uma semana depois, ocorreria um "grande festival literário dançante musical”, cuja animação ficaria a cargo do "jazz-band do maestro João Amaral”. ${ }^{32}$ Seriam entregues os prêmios para as moças mais bem votadas pelos leitores. A grande vencedora do certame foi a senhorita Laís de Moraes, "rainha da beleza campineira, orgulho de nossa raça” - brandiu o jornal Elite -,33 que obteve 875 votos, apenas 25 à frente da segunda colocada, Alice de Campos. A terceira colocação ficou com Luiza de Andrade, com os distantes 548 votos. Percebe-se o sucesso alcançado pelo concurso, uma vez que, em pouco mais de um mês de votação, foram computados 3.865 votos. 34

A partir dali, o número de bandas se multiplicou nas páginas dos jornais da imprensa negra: Jazz-Bands American, do maestro João Amaral; Jazz-Band Ba-ta-clan, do maestro Júlio Mariano; Jazz Elite e Liberdade, dirigida por Benedicto Vianna; Jazz Flores, dirigida por José de Barros; Jazz Floresta, Jazz Progresso, Jazz Buonavoglia e Moreno, entre muitas outras. Vale enfatizar que a década de 1920 constituiu um período de transição, tanto na nomenclatura e formação instrumental das orquestras, quanto na profissionalização dos músicos e das bandas. Muitas fontes assinalavam que determinado evento foi "abrilhantado" por uma orquestra de jazz, mas sem revelar o nome,35 ou

30 Canções em geral românticas, cujo estilo deriva das serestas boêmias que enchiam as ruas da cidade de São Paulo do século XIX, que poderiam englobar desde "trechos de óperas italianas" a canções "do povo", como as "valsas, quadrilhas, polcas, lundus e modinhas românticas" (MORAES, 1995, p. 130-138).

31 A Voz da Raça. São Paulo, 15 dez. 1934, p. 3.

32 Getulino. Campinas, 2 set. 1923, p. 3.

33 Elite. São Paulo, 20 jan. 1924, p. 4.

34 Getulino Campinas, 30 set. 1923, p. 3.

35 O Clarim d'Alvorada. São Paulo, 24 jun. 1926, p. 4; 24 out. 1926, p.4; 15 de jan. 1927, p. 6; Elite. São Paulo, 12 mar. 1924, p. 5; Progresso. São Paulo, 23 jun. 1928, p. 2; 15 nov. 1928, p. 5; dentre outros. 
apenas indicavam 0 maestro responsável. ${ }^{36}$ Também encontramos amiúde a denominação “orquestra”, 37 tão somente, o que preferimos não considerar jazz-band, apesar de estarmos cientes da linha tênue que, naquele cenário, separava os dois vocábulos. Com o passar dos anos, tornou-se mais importante especificar o nome da orquestra, quer para fins de propaganda do evento (os músicos, maestros e bandas paulatinamente iam adquirindo prestígio e admiradores), quer para demarcar posição, uma vez que crescia a quantidade dos músicos que viam nas bandas de jazz um campo de atuação profissional. Basta dizer que, tomando por base as edições d'A Voz da Raça apenas de 1933, identificamos sete jazz-bands cujos nomes não encontramos em toda a década de 1920, o que indica, assim, o crescimento da cena jazz entre os negros paulistas. 38

\section{Os maestros}

Com o desenvolvimento gradual das jazz-bands em São Paulo, cresceu também a importância atribuída a uma figura especial nesse contexto: os maestros. Eram os integrantes da banda de jazz que se responsabilizavam pelo conjunto harmônico e pelo andamento das apresentações. Em inglês, eles eram verdadeiros band-leaders.

Apesar de a expressão inglesa designar bem o papel dos maestros, foi nas orquestras brasileiras que a sua condição foi alçada aos mais altos patamares. O regente também denominado diretor de orquestra - era o principal personagem de uma jazzband, posição que lhe permitia ganhar os bônus quando o espetáculo era bem aceito, e os ônus quando do contrário. Muitas bandas traziam em seu nome a alcunha do seu maestro (como o Jazz Ademar), outras vezes não se fazia necessário saber o nome do conjunto, mas sim o do seu mestre. O Clarim d'Alvorada, por exemplo, ao dar aos seus leitores

36 O Clarim d'Alvorada. São Paulo, 25 jan. 1925, p. 4; 24 jan. 1926, p. 6; 24 jun. 1926, p. 4; 18 jun. 1927, p. 4; 3 fev. 1929, p. 3; Elite. São Paulo, 2 mar. 1924, p. 5; Progresso. São Paulo, 23 jun. 1928, p. 2; 23 jun. 1929, p. 5; dentre outros.

37 “Movimento Carnavalesco de 1924”. Elite. São Paulo, 2 mar. 1924, p. 4; “Festivais”. O Clarim d'Alvorada. São Paulo 7 dez. 1924, p. 4; por exemplo.

38 Eis as sete bandas encontradas nas edições d'A Voz da Raça de 1933: JAZZ BAND BICO DOCE, JAZZ ORQUESTRA DA F.N.B., JAZZ “FOLLIES”, JAZZ BATUTAS RIOCLARENCES, JAZZ ADEMAR, JAZZ ESMERO e JAZZ BAND ESPÍRITO SANTO. Cf. A Voz da Raça. São Paulo, 17 jun.1933, p. 3; 19 ago. 1933, p. 2; 16 set. 1933, p. 3; 23 out. 1933, p. 2; 11 nov. 1933, p. 2. 
notícias do "alto acontecimento" que fora a festa do grêmio Brinco de Princesas, em janeiro de 1929, revelou que "o jazz-band do conhecido musicista Juvenal de Campos esteve a contento de todos". 39 Quando o periódico Elite, em março de 1924, publicou duas notas sobre bailes carnavalescos, os nomes dos maestros ganharam destaque. A primeira divulgava "um movimentado baile à fantasia" sob os auspícios do clube 15 de Novembro. Programado para o sábado de carnaval, "só não se divertirá quem for aleijado. Pois, não há quem resista ao repertório de fino gosto da majestosa jazz-band dirigida pela sabida batuta... do maestro Badalaro". A segunda nota informava sobre um baile do clube Cravos Vermelhos, no domingo, evento “onde todos se divertem, deixando transparecer a nostalgia da vida, esquecendo-se desse modo do preço do feijão, da batata, do açúcar, etc...”. A nota finalizava com uma convocação: "Todos ao Cravos Vermelhos no Domingo Gordo, pois o maestro Vianna os espera com sua afinadíssima Jazz-Band". ${ }^{40}$ Essas passagens nos sugerem a importância dos maestros para as jazzbands.

Geralmente eles eram remanescentes das "orquestras de salão". Figuras estratégicas para esses antigos conjuntos musicais, continuaram exercendo tal papel ao aderirem ao jazz. Os regentes de orquestras que melhor se adaptaram ao novo contexto, o das "músicas modernas", se sobressaíram na cena jazz de São Paulo, ao menos no meio negro. Essa adaptação não deve ter sido muito difícil. Primeiro porque, como exposto, os ritmos norte-americanos já circulavam pelo país e eram executados pelas orquestras; segundo, porque o caminho natural das novas jazz-bands não foi a especialização, tout court, mas a fusão musical. Os diretores não montavam (ou transformavam) suas orquestras aos moldes de bandas de jazz "puras", "autênticas", antes eles incorporaram seletivamente o estilo ao seu vasto e sortido repertório, o que tornou a tarefa de "se atualizar" uma exigência do mainstream.

Para os anos 1920, a imprensa negra registrou mais nomes de maestros do que de bandas, o que reforça o seu papel-chave nesse contexto. Encontramos, no Getulino, os maestros João Amaral, Julio Mariano e Benedicto Vianna. ${ }^{41}$ No Clarim d'Alvorada, Antenor

\footnotetext{
39 O Clarim d'Alvorada. São Paulo, 3 fev. 1929, p. 3.

40 Elite. São Paulo, 2 mar. 1924, p. 5.

41 O Clarim d'Alvorada. São Paulo, 25 jan. 1925, p. 4; 24 jan. 1926, p. 6; 24 jun. 1926, p. 4; 24 out. 1926, p. 4; 18
} 
Carlos Vaz, Basílio dos Santos, Romeu França, Affonso Dias, Carlos Cruz, Juvenal de Campos, Conegunes e José de Barros. ${ }^{42}$ No Elite, vemos o maestro Badalaro 43 e, no Progresso, Benedicto dos Santos. ${ }^{44}$ Benedicto Vianna parece ter sido um conhecido diretor de orquestra, pois foi citado em mais de um jornal (Getulino, A Liberdade ${ }^{45}$ e Elite), assim como Juvenal de Campos, que apareceu tanto no Clarim d'Alvorada quanto no Progresso. 46

As bandas de jazz e seus maestros alcançaram prestígio no meio negro. Isso, contudo, não implicou a ascensão social daqueles profissionais, necessariamente. Adquirir certo status no meio musical propiciava melhores oportunidades e condições financeiras, uma vez que animar festas, bailes e eventos sociais com regularidade gerava visibilidade, novos convites, novos contratos e importantes dividendos para aqueles profissionais. Mas nada que pudesse levá-los a fazer fortuna, nem se considerarem astros do show business. De maneira geral, o prestígio desses jazzmen se dava entre os próprios negros, do ponto de vista de um capital menos econômico e mais simbólico, artísticocultural.

\section{Os eventos}

Para que as jazz-bands e seus regentes conquistassem tal prestígio, eles tinham que trabalhar. E trabalhar bastante. Mas onde? Quais os eventos que poderiam contar com o delirante "som das risadas metálicas do sumptuoso Jaz Band"?47 Vamos a eles.

Os principais locais onde se poderia ouvir às orquestras de jazz eram nos bailes. Talvez porque o "baile para nós”, escreveu Moysés Cintra em O Clarim d’Alvorada,48 “é a distração por excelência”, e lá "o jazz intransigente nos faz dançar; o seu mandato é prontamente cumprido". Ou ainda porque, segundo o articulista Montezuma, “dentre

jun. 1927, p. 4; 3 fev. 1929, p. 3; 18 ago. 1929, p. 4.

42 O Clarim d'Alvorada. São Paulo, 25 jan. 1925, p. 4; 24 jan. 1926, p. 6; 24 jun. 1926, p. 4; 24 out. 1926, p. 4; 18 jun. 1927, p. 4; 3 fev. 1929, p. 3; 18 ago. 1929, p. 4.

43 Elite. São Paulo, 2 mar.1924, p. 5.

44 Progresso. São Paulo, 23 jun. 1928, p. 2.

45 A Liberdade. São Paulo, 12 out. 1919, p. 3 ; 9 maio 1920, p. 2.

46 Progresso. São Paulo, 23 jun. 1929, p. 5.

47 O Clarim d'Alvorada. São Paulo, 27 dez. 1925, p. 2.

48 CINTRA, Moysés. "Nova Alvorada". O Clarim d'Alvorada. São Paulo, 15 out. 1927, p. 3. 
todos os divertimentos o que mais nos proporciona prazeres verdadeiros é, sem dúvida, o baile. [... Q Quer divertimento mais 'gostoso' que este? Não pode haver”. Montezuma, em seu libelo, concluía declarando que, com o baile, "tudo dança, ri, canta e... goza. Até as velhotas de coletes abarbatanados não se contem em suas cadeiras quando a batuta se agita num tentador fox-trot". ${ }^{49}$ Em suma, o "som contagiante" da jazz-band se encaixava perfeitamente com o precípuo objetivo dos bailes: a distração, o congraçamento e os momentos de intenso prazer.

Os clubes e associações negras eram os maiores organizadores de bailes. Muitos deles tinham na música a sua principal fonte de despesa. Dois casos são representativos disso: o primeiro é o do "Grêmio Dramático Recreativo Kosmos", que mantinha um jornal próprio, o Kosmos, e patrocinava seus costumeiros bailes. Em 1924, dos 5.901 contos de réis que a agremiação despendeu ao longo do ano, pelo menos 2.331 foram utilizados para pagar as orquestras contratadas. Somando os aluguéis dos salões, a despesa com bailes subia para 5.199 contos de réis, ou seja, mais de $88 \%$ do total da despesa anual do clube!50 O outro caso é o do Centro Recreativo Smart. No seu "balanço geral" apresentado à nova diretoria e referente ao mandato de 1919 a 1920, o clube registrou um gasto com “música” de 491\$500. Provavelmente valor da soma dos "cachês" dos músicos pagos ao longo do ano, que correspondia a cerca de $38 \%$ da despesa total do Smart (1.280\$900). Entretanto, consta ainda no “balanço geral” um item de despesa denominado "Salão", que se referia ao aluguel de um salão onde se realizava os bailes. Em um ano, esse gasto foi de $445 \$ 000$. Desse modo, o dispêndio com a contratação das orquestras, mais o custo do local onde os bailes ocorriam, soma $936 \$ 500$, o que significa cerca de $75 \%$ da despesa total do clube nesse período de 1919 e $1920 . .^{51}$ É bastante plausível que um determinado clube, que se autoproclamava "recreativo", empenhasse a maior parte do seu orçamento na promoção de atividades voltadas ao lazer. Todavia, o que mais nos chama a atenção é o fato de que a atividade de lazer por excelência desses clubes negros eram os bailes. E, nos anos 1920, bailes sob os acordes das jazz-bands.

\footnotetext{
49 Elite. São Paulo, 17 fev. 1924, p. 1.

50 O Kosmos. São Paulo, 25 jan. 1925, p. 2.

51 A Liberdade. São Paulo, 4 abr. 1920, p. 3.
} 
Dentre os bailes pautados pela imprensa negra nesse período, percebemos que existiam, por assim dizer, diversos tipos, sendo três os principais: os "ensaios", os "festivais" e os "bailes comemorativos". Os "ensaios" consistiam em bailes curtos, que aconteciam de maneira periódica - geralmente uma vez por semana. Não visavam festejar nada em especial, apenas proporcionar momentos de diversão e entretenimento aos seus frequentadores, como o Clube Recreativo Ituano, que oferecia "ensaios todas as terças-feiras", sempre alentados "por um excelente jazz-band”, 52 ou o Centro Recreativo Paulistano, que "há dez ou doze anos" vinha "dando ótimas festas". Seus "ensaios domingueiros, ao som de afinado jazz-band", ocorriam periodicamente. 53 Já os “festivais" eram bailes de maior monta, sem regularidade predefinida e comumente divididos em partes. O mesmo evento poderia reunir: partes dramáticas, com a encenação de pequenos espetáculos ou performances teatrais, protagonizados por membros da própria agremiação; partes literárias, com declamações de poesias e outros textos; partes solenes, com discursos de autoridades (presidentes e diretores de clubes, jornalistas, professores, advogados negros etc.) e, como ponto culminante, partes musicais, que costumavam ser as últimas. Foi o caso do festival organizado pelo G. D. Luiz Gama de Campinas, em dezembro de 1924. Realizado no salão "Casino", com início às 20h30, "precisamente", o festival obedeceu à seguinte programação:

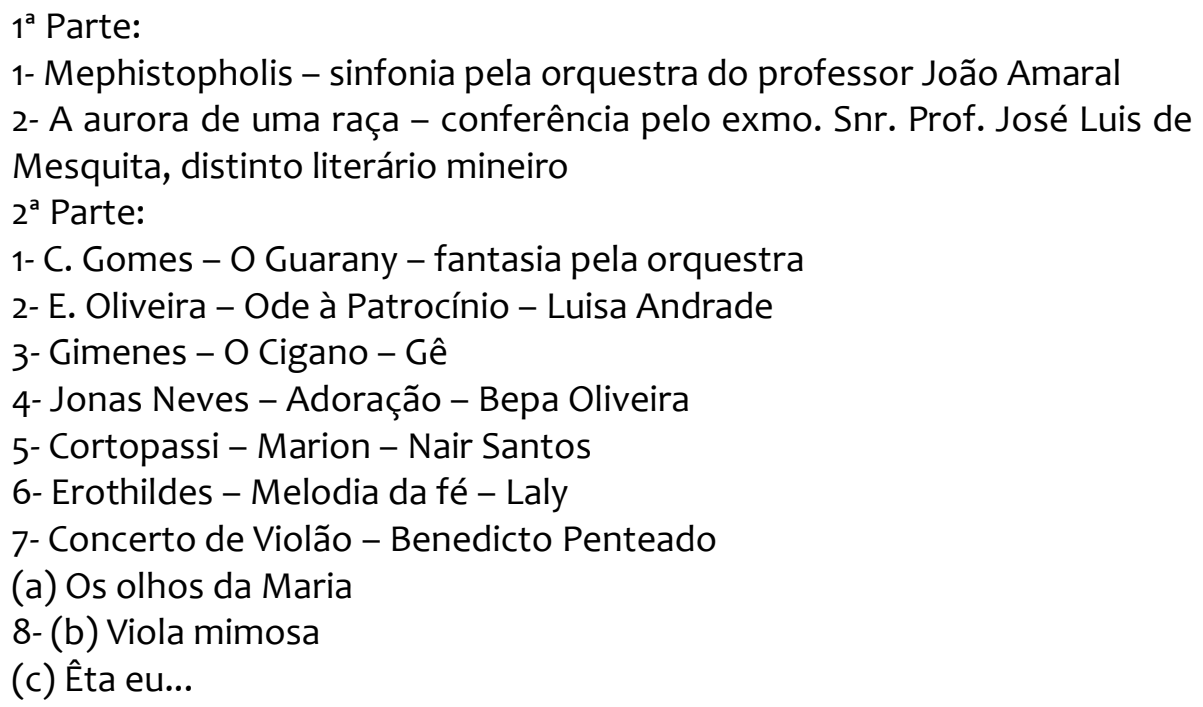

2 Progresso. São Paulo, 28 abr. 1929, p. 5.

53 Progresso. São Paulo, 23 jun. 1928, p. 2. 
Até ali, a tertúlia não dava sinais de trégua, pois "findo o espetáculo", a diretoria do clube ofereceu às "exmas. famílias um baile com o concurso de um ótimo Jazz do maestro Amaral”. Finalmente, houve o desfecho do aparatoso festival, cuja programação foi formada por uma " $1^{a}$ parte" solene, com destaque para a conferência do professor José Luis de Mesquita; por uma " $2^{\mathrm{a}}$ parte” lítero-dramática, com declamações de poesias e performances teatrais, e por uma última - e a mais concorrida - parte, o baile, sob a batuta do "Jazz do maestro Amaral". 54

Os "bailes comemorativos", o terceiro tipo de reunião músico-dançante, eram festividades que ocorriam em razão das datas que diziam respeito ao negro (como o 13 de Maio especialmente e, em menor intensidade, o 28 de Setembro) e dos eventos significativos para os clubes, tais como o aniversário da sua fundação, a posse de nova diretoria, a criação de departamento específico. As comemorações começavam com sessões solenes, das quais participavam os dirigentes dos clubes, autoridades e convidados. Além dos discursos de praxe, ocorriam declamações e encenações diversas. Em geral, o baile encerrava as comemorações. Esse foi o caso da festa patrocinada pelo Clube 28 de setembro que, "em comemoração à data do mesmo nome", realizou "uma sessão solene, presidida pelo presidente em exercício", na qual se ouviram as vozes de “J. Aguiar [redator do Clarim d'Alvorada], Deocleciano Nascimento [poeta negro de destaque] e Luís Gonzaga da Silva”. Assim que terminou a sessão solene, deu-se “início ao baile, ao som de um bem organizado jazz que se prolongou até ao romper da aurora".55 Na comemoração em regozijo ao seu aniversário, o clube "Cravos Vermelhos" também ofereceu, em 1924, uma "partida dançante que se revestiu de todo o brilhantismo", “constando de sessão solene presidida pelo seu presidente sr. Norberto Rocha". Em seguida, iniciou-se o "baile que se prolongou até alta madrugada ao som do excelente Jazz Band do conhecido maestro Affonso Dias". ${ }^{56}$

Afora essas três tipificações de bailes, ocorriam em menor escala os "chás dançantes", as soirées e as "matinês dançantes". Esses eventos, embora não comemorassem alguma efeméride ligada à história do negro, nem festejassem qualquer

54 Getulino. Campinas, 20 dez. 1924, p. 3.

55 O Clarim d'Alvorada. São Paulo, 24 out. 1926, p. 4.

56 O Clarim d'Alvorada. São Paulo, 24 out. 1926, p. 4. 
acontecimento especial relacionado aos clubes, costumavam ser musicados. Seja como for, os bailes das agremiações negras em São Paulo se constituíram em espaços privilegiados para os espetáculos das jazz-bands. O próprio sentido "bailante" do evento se coadunava com a sonoridade alegre e vibrante das “danças modernas".

Mas não era só em bailes que se podia ouvir o jazz. O sucesso alcançado pelas bandas do gênero fez com que elas fossem também contratadas para animar eventos familiares, como casamentos, aniversários e batizados. A comemoração do dia do nascimento do senhor Juvenal R. de Souza, como foi noticiada no Clarim d'Alvorada, é exemplo disso:

Completou à 25 de março findo mais um natalício este prezado amigo e leitor assíduo dessa folha; por esse motivo reuniu em sua residência sita à rua Caetano Pinto, 178, pessoas amigas oferecendo-lhes uma lauta mesa de doces e um excelente baile ao som de um bem organizado Jazz-Band, sendo muito cumprimentado pelos amigos inúmeros que o felicitaram. ${ }^{57}$

Os pais da "galante Irene", “o sr. Octávio Alves Correia e sua exma. esposa d. Maria A. Correia", também resolveram festejar o aniversário da filha ao som do “apreciadíssimo Jazz Floresta, composto de elementos de nossa classe [de "homens de cor"], que souberam prestigiar o evento ${ }^{58}$. Também com jazz foi regado o batizado de “Adelina, a graciosa filhinha do sr. José Maria da Cruz e sua exma. esposa D. Epiphania L. da Cruz". Para celebrar "tão auspicioso acontecimento, os pais da criança ofereceram aos convidados um animado baile, que foi abrilhantado pelo querido Jazz Flores".59

Verificamos, assim, que as jazz-bands podiam "abrilhantar", tanto os mais pulsantes regabofes dos clubes, os mais frementes bailes, inclusive de carnaval, ${ }^{60}$ quanto as tradicionais reuniões sociais de caráter familiar. Sua sonoridade passou a ser desejada nos mais diversos eventos festivos, na esfera pública e privada. O que nos leva a crer que, ao longo dos anos 1920, o jazz fez um sucesso descomunal entre os negros de São Paulo. Ciente disso, alguns músicos não perderam a oportunidade de racializar o perfil de suas

\footnotetext{
57 O Clarim d'Alvorada. São Paulo, 17 abr. 1924, p. 4.

58 O Clarim d'Alvorada. São Paulo, 14 jul. 1929, p. 2.

59 O Clarim d'Alvorada. São Paulo, 18 ago. 1929, p.4.

60 Elite. São Paulo, 2 mar. 1924, p. 5, dentre outros.
} 
bandas, a fim de conquistarem mais espaço para trabalhar ou se inserir no mainstream. Assim fez o "Black American Jazz", grupo musical que foi "fundado pelo sr. Eurico Silva” e contava "exclusivamente com elementos Black". Tomando "parte os melhores e conhecidos músicos desta capital", anunciou o Clarim d'Alvorada em abril de 1930, o grupo atendia a "chamados para: soirées, casamentos, chás dançantes; enfim, para toda e qualquer festa que dependa de um bom JAZZ-BAND". ${ }^{61}$

\section{As mulheres no jazz}

A história do jazz no meio negro paulista contou com a presença das mulheres, ainda que estas enfrentassem uma série de obstáculos para serem aceitas socialmente, sobretudo nos espaços públicos. Não é para menos. As relações de gênero predominantes eram plasmadas em termos de dominação/subordinação. ${ }^{62} \mathrm{Um}$ artigo publicado no Getulino, em setembro de 1923, é o que provavelmente melhor sintetizava essa visão: "A mulher foi criada para mãe, para doce companheira do homem, e nesse conceito, a sua constituição física e moral é para o completo desenvolvimento de tal missão". Do ponto de vista da "influência social da mulher", postulava o articulista, seria uma afronta à "ordem natural da sua verdadeira condição" se, por "força de enérgicos empenhos e por torturas de seu pensamento", ela "chegasse a atingir os cargos reservados aos homens", se valendo da "negra toga do austero magistrado", a "gorra do marítimo" ou a "estreita calça do soldado". ${ }^{63}$

Se à mulher negra não deveria ser facultado o acesso aos ditos "cargos reservados aos homens", a profissão de músico era certamente um deles. Óbvio que havia mulheres que estudavam e se dedicavam à música e até faziam apresentações esporádicas fora do ambiente doméstico. Porém, exercer regularmente a profissão, tocando em bandas masculinas - que animavam bailes até altas horas da madrugada, não há registros. Ou pelo menos não encontramos algum caso nas fontes consultadas. O que não significa

\footnotetext{
61 O Clarim d'Alvorada. São Paulo, 13 abr. 1930, p. 2.

62 Sobre as relações de gênero no Brasil nesse período, intersecionando a condição da mulher negra, ver BESSE, 1999; CAULFIELD, 2000.

63 Getulino. Campinas, 2 set. 1923, p. 1.
} 
dizer que as mulheres negras ficaram ausentes ou indiferentes à onda do jazz. Sua postura proativa é digna de nota.

Além de serem boa parte dos partícipes dos bailes - momentos nos quais ostentavam um vestido novo, um comportamento, penteado e padrão estético da moda; dançavam, conversavam, flertavam ou simplesmente prestigiavam as bandas -, as mulheres desempenhavam um papel logístico estratégico, o de organizadoras. Conforme reportado n'A Voz da Raça, um "grupo de gentis senhoritas de escol do bairro da Vila Mariana”, nomeadamente “Rosa, Deolinda, Cecília, Siria, Joanna, Benedita”, organizaram uma "encantadora festa", onde "foi oferecido no decorrer da mesma uma lauta mesa de finos doces e sanduiches regado de saborosos vinhos e licores". ${ }^{64} \mathrm{Na}$ comissão organizadora do "sarau dançante", impulsionado pela Frente Negra Brasileira em homenagem a Isaltino Veiga dos Santos (um dos fundadores da agremiação), constavam os nomes de Engracia Hortencio, Anacleta Aurelio da Silva, Antonia Lucrecio e Benedita Costa. 65

Nesse ímpeto, podemos listar também as associações recreativas formadas estritamente por mulheres negras, ou mesmo as seções femininas de clubes negros, como agências fomentadoras de bailes sob os acordes inexoráveis de jazz-bands. 0 “quadro de damas" do Clube 13 de Maio, por exemplo, organizou o "Baile Cor de Rosa", um "belo festival dançante", que transcorreu no sábado à noite de 17 de janeiro de 1925. ${ }^{66}$ Por sua vez, o Grêmio Recreativo Brinco de Princesas - como o próprio nome sugere, uma agremiação de mulheres - especializou-se na promoção de bailes, como em 26 de junho e 6 de outubro de $1926^{67}$ e em fevereiro de $1929 .{ }^{68}$ Afora o Brinco de Princesas, outras sociedades femininas também ofereciam bailes, como Arte Culinária, Rosas Negras e Grupo das Margaridas. ${ }^{69}$

Embora não seja uma tarefa fácil mapear a participação das mulheres negras na cena jazzística, encontramos indícios e pistas que nos permitem sugerir que elas se viram

\footnotetext{
64 A Voz da Raça. São Paulo, 13 maio 1933, p. 2.

65 A Voz da Raça. São Paulo, 19 ago. 1933, p. 2.

66 O Clarim d'Alvorada. São Paulo, 25 de jan. 1925, p. 4.

67 O Clarim d'Alvorada. São Paulo, 20 jun. 1926, p. 4; O Clarim d'Alvorada. São Paulo, 24 out. 1926, p. 4.

68 O Clarim d'Alvorada. São Paulo, 3 fev. 1929, p. 3.

69 A Voz da Raça. São Paulo, 23 out. 1933, pg.2; Progresso. São Paulo, 12 de out. 1928, p. 3.
} 
inclinadas às "músicas e danças modernas" e fomentaram, na medida do possível, eventos embalados pelas trepidantes jazz-bands. É bom que se diga: longe de esgotar o assunto, neste tópico demos apenas o primeiro passo. Muito ainda permanece envolto numa cortina de fumaça. Possivelmente, a importância feminina na dinâmica cultural da população negra no período foi maior do que conseguimos rastrear.

\section{O "circuito" das jazz-bands}

À luz de pesquisas nos domínios da antropologia urbana, José Guilherme Magnani define o circuito como sendo uma "configuração espacial, não contínua, produzido pelos trajetos de atores sociais no exercício de alguma de suas práticas, em dado período de tempo". O antropólogo faz observações importantes: o circuito se caracteriza pela inserção espacial, como também pela dimensão temporal. Por seu intermédio, é possível “identificar e descrever um conjunto de pontos localizados espacialmente ao longo dos quais determinadas pessoas, objetos, mensagens se movimentam durante certo período de tempo" (MAGNANI, 2014). Os bailes sob os acordes das jazz-bands conformavam uma espécie de circuito, no sentido de que, em vez de isolados, aleatórios e esporádicos, aqueles eventos protagonizados pela população negra delineavam uma configuração espacial, eram dotados de sentidos próprios e se conectavam em torno da música, elemento comum a partir do qual se demarcavam regularmente itinerários, identidades e ocupações concêntricas.

Consultando a coleção dos jornais da imprensa negra, procuramos exaustivamente por informações que indicassem a localidade dos bailes musicados pelas jazz-bands na capital paulista. Por serem jornais alternativos, muitas vezes de pequena tiragem, ${ }^{70}$ essas informações nem sempre apareciam em suas edições. Provavelmente por já serem de conhecimento prévio dos leitores. Com efeito, coletamos e cruzamos alguns dados e elaboramos um mapa com os lugares onde transcorriam aqueles eventos (mapa 1). A partir daí, é possível tecer algumas considerações.

\footnotetext{
70 Exceção feita ao O Clarim d'Alvorada e A Voz da Raça, jornais de maior circulação.
} 
Não há registros de bailes nos bairros de Campos Elíseos, Higienópolis, Vila Buarque, enfim, nos bairros considerados nobres da cidade na época. Isso é importante para se ter uma noção de onde se situava socialmente esse circuito. Por outro lado, os bailes, em sua esmagadora maioria, não eram realizados nas áreas tradicionalmente associadas à comunidade negra - Lavapés, Bexiga, Alameda Glete, por exemplo (ROLNIK, 1988). O mapa mostra que a maior concentração daqueles eventos se localizava na zona imediatamente circundante ao atual centro velho paulistano, distribuindo-se pelas ruas Florêncio de Abreu, do Carmo, Quintino Bocaiúva, 25 de Março, Praça João Mendes, em suma, pelo distrito da Sé e seu entorno.

Isso ocorria pela facilidade de acesso de um segmento populacional que tendia a habitar em bairros populares mais distantes, mas também pela perspectiva de conferir maior visibilidade pública à presença negra na cidade. Afinal, a região central era considerada uma vitrine simbólica do progresso, da civilização, do refinamento e da modernidade, legitimando-se como um dos principais cartões postais da pauliceia desvairada. Não é sem motivos, portanto, que muitas sociedades recreativas negras, principalmente as mais organizadas, ali estabeleceram sede social. As informações a respeito referem-se ao Grêmio Recreativo Kosmos, à Associação São Geraldo, que mantiveram sedes na Rua Florêncio de Abreu; às sociedades recreativas Elite da Liberdade e Flor da Mocidade, que ocuparam, talvez por épocas diferentes, a mesma sede, à Rua Barão de Paranapiacaba, à Sociedade Princesa do Norte, com sede à Rua Quintino Bocaiúva, sem falar da Frente Negra Brasileia, que funcionou provisoriamente em duas salas do palacete Santa Helena, edifício existente na Praça da Sé, e depois se instalou num casarão da Rua da Liberdade.

Entretanto, para várias sociedades negras desse período, não há indicação sobre o local onde estavam instaladas as sedes, com algumas das quais, inclusive, desprovidas de qualquer referência à existência de um local fixo. Talvez por isso, muitas dessas sociedades alugavam salões para as realizações de seus eventos sociais, notadamente os bailes. Os chamados "salões da raça" (MORAES, 2000, p. 262), situados na região central da cidade, atraíam um contingente populacional que sentia necessidade de se encontrar regularmente para dançar, estabelecer laços de amizade e, de alguma forma, vivenciar o 
pertencimento a um grupo social mais amplo que a simples unidade familiar (SILVA, 1998, pp. 65-96; SIMSON, 2007). Era nesses bailes, dos clubes dançantes, que os negros provenientes dos mais diferentes bairros paulistanos compareciam, interagindo e compartilhando determinados interesses, valores, mundividências e modo de vida.

Os relatos salientam que esses bailes ocorriam todas as semanas, em certos dias. Eram ocasiões de confraternização entre os membros dos clubes, além de oportunidade de dançar e ouvir uma boa música de uma jazz-band. Os jovens se sentiam particularmente seduzidos por essa atividade, por lhes possibilitar um contato com pessoas da mesma faixa etária e mesma origem racial. Em livro de memórias, José Correia Leite, uma antiga liderança negra desse período, informa que os bailes eram "algo indispensável”. Cobrava-se a entrada, "pois era muito difícil manter um corpo associativo. Com exceção dos diretores, a maioria pagava ingresso". Se o indivíduo quisesse, “dançava de segunda a segunda” (LEITE, 1992, p. 45-46). Havia normas organizativas bem definidas para a realização dos bailes, com tentativas de controle sob o perfil dos frequentadores e supervisão constante dos membros mais velhos dos clubes, que zelavam pelo bom andamento da festa.

Os bailes consistiam numa atividade mantenedora do vínculo entre os membros da agremiação, afora significar a principal fonte de renda para cobrir as despesas do salão e do conjunto musical. O Clube Negro de Cultura Social, por exemplo, contratava uma pequena orquestra para animar os bailes aos domingos. Era na verdade um conjunto musical com cinco membros (pistom, bateria, banjo, clarineta e baixo-tuba), chamado de “jazz” pelos integrantes da agremiação. Como os bailes eram concorridos e atraíam uma legião de jovens negros de toda a cidade, as arrecadações da bilheteria permitiam que o clube arcasse com as despesas do aluguel do salão e da contratação do conjunto musical. ${ }^{71}$

Cada vez mais numerosos na década de 1920, os bailes se inseriam numa rede de conexões culturais, de práticas, estilos, repertórios e equipamentos, configurando-se em lugares de encontro e passagem que acenavam símbolos de distinção na paisagem

\footnotetext{
71 Sobre aspectos da trajetória desse clube, ver DOMINGUES, 2004, p. 57-79.
} 
urbana. Como o público-alvo era o mesmo, os eventos tendiam a se reeditar, bem como as atrações. A banda do maestro Benedito Viana se apresentou na "Matinée chic" do jornal A Liberdade, em abril de $1920,7^{72}$ e no baile de aniversário do clube Elite da Liberdade, em outubro de $1924 .{ }^{73}$ Por seu turno, a banda do maestro Afonso Dias animou a "soireé chá dançante" do Grêmio Recreativo Brinco de Princesas em outubro de 1926 e, apenas dois dias depois, o baile em comemoração da data natalícia do clube Cravos Vermelhos, no Salão Victoria, localizado na Rua Quintino Bocaiúva, ${ }^{74}$ ao lado da praça da Sé.

Esses vários "salões da raça” concentrados na região central de São Paulo, com os seus bailes aglutinadores e frenéticos, constituíam o principal fulcro do circuito do jazz, um circuito cujos frequentadores, vindos de várias partes da cidade, não necessariamente se conheciam (por laços de vizinhança, parentesco, trabalho, religião, como no contexto do bairro) mas se reconheciam, seja pela identificação racial, seja pela exibição de sinais diacríticos, nos cortes de cabelo, na linguagem visual ou na postura corporal, evidenciando seus gostos musicais, o pertencimento a determinados grupos de amizade, a preferência por esta ou aquela banda etc.

Por meio daqueles eventos festivos, a população negra expressava seus desejos e expectativas de instituir espaços próprios, onde pudesse participar da vida pública e cultural da cidade, mesmo que isso implicasse em se manter nos limites da "linha de cor". Nesses bailes sob a batuta das jazz-bands, mulheres e homens de pele escura estabeleciam contatos, trocavam experiências, teciam laços de união, solidariedade e costumes em comum; esqueciam as agruras do dia a dia e se deleitavam "pacas", sem contar que desenvolviam ou reforçavam uma identidade racial, com seus estilos e padrões comportamentais enfeixados pela música símbolo da modernidade.

\footnotetext{
A Liberdade. São Paulo, 9 maio 1920, p. 2.

3 Getulino. Campinas, 5 out. 1924, p. 3.

74 O Clarim d'Alvorada. São Paulo, 24 out. 1926, p. 4.
} 


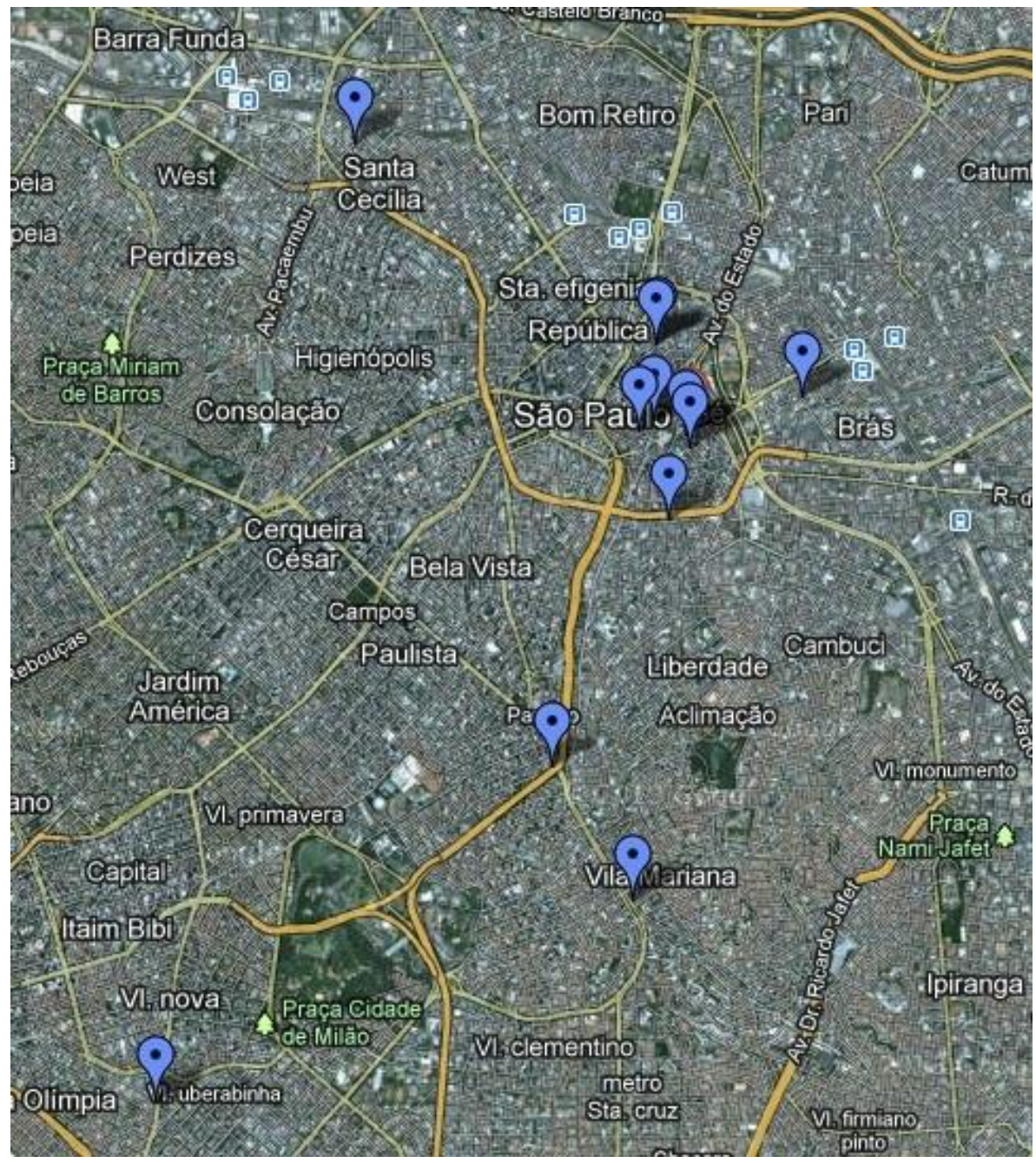

Figura 1 Mapa dos bailes negros com jazz-bands em São Paulo (1924-1934)

$* * *$

Ao se abrir a porta da história de São Paulo nos anos 1920, observamos como a "era do jazz" revelou-se uma manifestação cultural impactante e de grande relevância para as pessoas negras do estado, particularmente da capital. Captando o que de mais moderno estava circulando ao redor do mundo Atlântico, esse segmento populacional incorporou o jazz à sua miríade de sonoridades, adotando-o a partir de seus próprios termos.

Depois desse passeio pelo cenário jazzístico no meio afropaulista, já podemos responder às perguntas ventiladas na parte inicial do artigo. $O$ primeiro ponto a se ressaltar é que não podemos dizer que as "músicas modernas", entre Estados Unidos e 
Brasil, foram experimentadas da mesma forma. Lá, um compilado de estilos - ragtime, cake-walk, one-step, two-step, fox-trot - fundiu-se sob a genérica rubrica de jazz, que se tornou música popular e virou epidemia nacional. Assim, as jazz-band se formaram para tocar esse novo gênero musical, tout court. Já no Brasil, as bandas de jazz foram mais plurais e versáteis, apropriando-se do gênero norte-americano como mais uma - e não a única - expressão musical. Quando os rítmicos jazzísticos chegaram ao país e se tornaram a sensação da vez, já havia uma gama de sonoridades que compunha o cancioneiro nacional (maxixes, sambas, marchas, choros, cateretês, rancheiras, emboladas sertanejas) e popular (valsas, polcas, tangos), sonoridades estas que não foram encapsuladas sob o codinome jazz. Portanto, as jazz-bands à brasileira foram criadas para tocar as músicas modernas norte-americanas sem, contudo, abrirem mão de seu "vasto repertório" tradicional (e local). ${ }^{75}$

Também pudemos notar como essas orquestras "jazz-bandicas” se organizavam. Instrumentalmente, eram formadas por uma maioria de sopros, principalmente o saxofone, o trombone e o trompete, responsáveis pelas melodias das canções; outra parte de cordas e teclas, com o piano sendo fundamental para a banda, auxiliado por banjos, violinos e violões na parte harmônica e rítmica e, para completar, a bateria, grande símbolo do jazz. A cadência, o andamento sincopado e as variações rítmicas proporcionadas pelo baterista produziriam o "espírito" do estilo, sua grande peculiaridade frente aos demais existentes no país.

As jazz-bands eram via de regra comandadas pela batuta do maestro da orquestra. Era ele quem definia e, quando necessário, improvisava o repertório de cada apresentação, sendo o responsável pela qualidade e performance do conjunto. Se regesse a banda com expertise e talento, sabendo impressionar e agradar ao público, colocandoo para dançar e se divertir em estado de frenesi, seria reconhecido e sempre lembrado, tanto pelos frequentadores dos bailes, quanto pelos seus promotores, como parece ter sido o caso dos maestros Benedito Vianna, Juvenal de Campos e Conegunes.

\footnotetext{
75 Essa assertiva corrobora o que as pesquisas recentes têm apontado. Ver GILLER, 2013; LABRES FILHO, p. 75; ABREU, 2017.
} 
Não havia um tipo específico de evento que contava com o "som contagiante das jazz-bands", mas o baile era o seu principal lócus. Quer os bailes “comemorativos”, quer os "festivais" e os "ensaios", costumavam ser musicados pelas diversas orquestras. Os “chás dançantes" e soirées, assim como as festividades familiares (casamentos, aniversários e batizados), também se tornaram espaços privilegiados para quem desejava ouvir e dançar as "músicas modernas". O sucesso vertiginoso que as jazz-bands alcançaram nos clubes e "salões da raça" possibilitou o surgimento de novas oportunidades de trabalho, que foram bem aproveitadas pelos pistonistas Bonfilho de Oliveira, Justo e outros músicos negros.

Esse mainstream foi lidado de maneira diferenciada pelas mulheres negras. Inserirse na atividade musical demandava aprender a tocar um instrumento e geralmente ler partituras, ficar longas horas fora de casa, ensaiando e se apresentando nos bailes, que muitas vezes rompiam a madrugada; estar à disposição para viagens constantes pelo interior do estado e tudo o que a vida de músico profissional exigia, o que contrastava com os papéis sociais atribuídos às mulheres. Apesar disso, elas se enfronharam naquela ambiência jazzística, cumprindo até um papel de destaque nas comissões organizadoras dos bailes.

Verificamos, ainda, como a maior parte desses bailes ocorria nas sedes dos clubes dançantes negros, quando não nos "salões da raça" alugados no atual centro velho paulistano, notadamente no perímetro adjacente à Praça da Sé. Estar ali significava demarcar posição numa região bem localizada, no plano geográfico, e distintamente conceituada e sofisticada, do ponto de vista social. Essa concentração de bailes sob a órbita dos shows das jazz-bands na capital paulista engendrou o que denominamos de circuito, uma rede de interconexões envolvendo artistas (maestros e orquestras) intermediários culturais (produtores dos eventos e divulgadores), formadores de opinião e rumores (jornais da imprensa negra) e público-alvo, negras e negros oriundos dos mais diferentes bairros da cidade, sobretudo da periferia, com seus estilos de vida - hábitos de consumo, códigos de vestimenta, gostos musicais etc.

Por fim, acreditamos que esses bailes faziam sucesso porque o público-alvo se identificava com o jazz - devido especialmente à sua origem afro-diaspórica, que se 
converteu no principal símbolo musical da modernidade -, mas também porque esse público compartilhava de dois elementos comuns à maioria das experiências e culturas africanas e diaspóricas: o lúdico e a corporalidade. Esses dois elementos têm importantes significados nos modos de pensar, sentir e agir das pessoas africanas e negras de modo geral. Os bailes, sob os rítmicos jazzísticos, constituíam um espaço social em que a corporalidade era vivenciada profundamente. A atitude de dançar articulava-se à música e à festa, não podendo ser pensada separadamente. Aqueles bailes assumiam o sentido de eventos de celebração do jazz e a um só tempo de ludicidade, momentos em que homens e mulheres "de cor" encontravam os semelhantes e dividiam alegrias, tristezas, esperanças, sonhos e utopias; (re)inventavam subjetividades, buscavam o prazer na música, na dança, no clima de euforia e descontração, esbaldando-se nos criativos lenitivos modernos para as adversidades da vida.

\section{Referências}

ABREU, Martha. Da senzala ao palco: canções escravas e racismo nas Américas, 18701930. Campinas: Ed. Unicamp, 2017.

ALBERTO, Paulina L. Terms of inclusion: black intellectuals in twentieth-century Brazil. Chapel Hill, N.C.: The University of North Carolina Press, 2011.

ANDREWS, George Reid. Negros e brancos em São Paulo (1888-1988). Bauru, SP: EDUSC, 1998.

BARSALINI, Leandro. Sobre baterias e tamborins: as jazz bands e a batucada de samba. Revista do Instituto de Estudos Brasileiros. São Paulo, n. 70, ago. 2018, p. 59-77.

BASTIDE, Roger. A imprensa negra do estado de São Paulo. Sociologia: boletim da Faculdade de Filosofia, Ciência e Letras da Universidade de São Paulo, São Paulo, v. 121, n. 2, 1951, p. 50-78.

BESSE, Susan. K. Modernizando a desigualdade: reestruturação da ideologia de gênero no Brasil, 1914-1940. São Paulo: Edusp, 1999.

BILLARD, François. No mundo do jazz. São Paulo: Companhia das Letras, 2001. 
BLAKE, Jody. Le tumulte noir: modernist art and popular entertainment in jazz age Paris, 1900-1930. University Park, PA: Pennsylvania State University Press, 1999.

BORGE, Jason. Tropical riffs: Latin America and the politics of jazz. Durham: Duke University Press, 2018.

BUTLER, Kim D. Freedoms given, freedoms won: afro-brazilians in post-abolition São Paulo and Salvador. New Brunswick, NJ: Rutgers University Press, 1998.

CABRAL, Sérgio. Pixinguinha: vida e obra. 4. ed. Rio de Janeiro: Funarte, 2007.

CAULFIELD, Sueann. Em defesa da honra: moralidade, modernidade e nação no Rio de Janeiro (1918-1940). Campinas, SP: Ed. Unicamp, 2000.

DOMINGUES, Petrônio. Paladinos da liberdade: a experiência do Clube Negro de Cultura Social em São Paulo (1932-1938). Revista de História, São Paulo, n. 150, 2004, p. 57-79.

DOMINGUES, Petrônio. Os jornais dos filhos e netos de escravos (1889-1930). A nova abolição. São Paulo: Selo Negro, 2008, p. 19-58.

FERRARA, Miriam Nicolau. A imprensa negra paulista (1915-1963). São Paulo: FFLCH/USP (Antropologia 13), 1986.

FERRO, Antonio. A idade do jazz-band. São Paulo: Off. Graph. Monteiro Lobato \& CO., 1922.

ITZGERALD, Scott F. Seis contos da era do jazz. 2. ed. Rio de Janeiro: Civilização Brasileira, 1965.

FLOREAL, Sylvio. Ronda da meia-noite: vícios, misérias e esplendores da cidade de São Paulo. São Paulo: Paz e Terra, 2003.

GILLER, Marilia. O Jazz no Paraná entre 1920 a 1940: um estudo da obra O sabiá, fox trot shimmy de José da Cruz. Dissertação (Mestrado em Música) - Universidade Federal do Paraná, Curitiba, 2013.

HOBSBAWM, Eric. História social do jazz. Rio de Janeiro: Paz e Terra, 2009.

IKEDA, Alberto. Apontamentos históricos sobre o jazz no Brasil: primeiros momentos. Comunicação e Artes, São Paulo, n. 13, p. 111-124, 1984.

LABRES FILHO, Jair Paulo. Que jazz é esse? As jazz-bands no Rio de Janeiro da década de 1920. Dissertação (Mestrado em História) - Universidade Federal Fluminense, Niterói, 2014. 
LEITE, José Correia. E disse o velho militante José Correia Leite: depoimentos e artigos. Organizado por Cuti. São Paulo: Secretaria Municipal da Cultura, 1992.

MAGNANI, José Guilherme Cantor. O Circuito: proposta de delimitação da categoria. Ponto Urbe [Online], São Paulo, n. 15, 2014.

MARTINS, Luiza Mara Braga. Os oito batutas: história e música brasileira nos anos 1920. Rio de Janeiro: Ed. UFRJ, 2014.

MORAES, José Geraldo Vinci de. Sonoridades paulistanas: final do século XIX ao início do século XX. Rio de Janeiro: Funarte, 1995.

MORAES, José Geraldo Vinci de. Metrópole em sinfonia: história, cultura e música popular na São Paulo dos anos 30. São Paulo: Estação Liberdade, 2000.

PENTEADO, Jacob. Memórias de um postalista. São Paulo: Editora Martins, 1963.

PINTO, Regina Pahim. O movimento negro em São Paulo: luta e identidade. Ponta Grossa: Ed. UEPG; São Paulo: Fundação Carlos Chagas, 2013.

PIRES, Antônio Liberac Cardoso Simões. As associações de homens de cor e a imprensa negra paulista. Belo Horizonte: Daliana - MEC/SESU/Secad - Neab/UFT, 2006.

REIS, Ruan Levy Andrade. Letras de fogo, barreiras de lenha: a produção intelectual negra paulista em movimento (1915-1931). 2017. Dissertação (Mestrado em História). Universidade de São Paulo, São Paulo, 2017.

ROLNIK, Raquel. Territórios negros em São Paulo: uma história. 1988. Comunicação apresentada na XVI Reunião da Associação Brasileira de Antropologia, Campinas, Unicamp, 1988.

SEIGEL, Micol. Uneven encounters: making race and nation in Brazil and The United States. Durham, NC: Duke University Press, 2009.

SEVCENKO, Nicolau. Orfeu extático na metrópole: São Paulo sociedade e cultura nos frementes anos 20. São Paulo: Companhia das Letras, 1992.

SEVERIANO, Jairo; MELLO, Zuza Homem de. A canção no tempo: 85 anos de músicas brasileiras. v. 1: 1901-1957. São Paulo: Ed. 34, 1997.

SHAW, Lisa. Tropical travels: brazilian popular performance, transnacional encounter, and the construction of race. Austin: University of Texas Press, 2018.

SILVA, José Carlos Gomes da. Negros em São Paulo: espaço público, imagem e cidadania. 
In: Ana Maria de Niemeyer e Emília Pietrafesa de Godói (Orgs.). Além dos territórios: para um diálogo entre a etnologia indígena, os estudos rurais e os estudos urbanos. Campinas: Mercado Aberto, 1998.

SIMSON, Olga Rodrigues de Moraes von. Carnaval em branco e negro: carnaval popular paulistano (1914-1988). Campinas, Editora da Unicamp; São Paulo: Editora da Universidade de São Paulo; Imprensa Oficial do Estado de São Paulo, 2007.

STEARNS, Marshall W. A história do jazz. São Paulo: Livraria Martins, 1956.

TINHORÃO, José Ramos. História social da música popular brasileira. Rio de Janeiro: Editora 34, 1998.

VASCONCELLOS, Ary. Panorama da música popular brasileira na Belle Époque. Rio de Janeiro: Martins: Livraria Sant'Anna, 1977.

VELLOSO, Rafael H. S. "The Saxophone in Choro: The introduction of the saxophone and the changes in the performance of the choro style of music". In: MAKING MUSIC, MAKING MEANIG: 13th Biennial Conference of the International Association for the Study of Popular Music (IASPM). Roma:IASPM, 2005, p. 813-819. 